\title{
Evaluation of School-Based Management (SBM) Implementation in Basic School Using Context, Input, Process, and Product Models
}

\author{
Yurni Rahman \\ Faculty of Teacher Training and \\ Education \\ Muhammadiyah University of \\ Gorontalo \\ Gorontalo, Indonesia \\ yurnirahman@umgo.ac.ids
}

\begin{abstract}
The purpose of this study was to (1) evaluate the Management of Primary Schools (SBM) in SD Negeri 61 District Timur Timur Gorontalo City; (2) evaluate the input of SBM in SD Negeri 61, Kota Timur District, Gorontalo City; (3) evaluate the Management of Primary Schools (SBM) in SD Negeri 61, Kota Timur District, Gorontalo City; (4) evaluate the School-Based Management Project (SBM) in the Public Elementary School 61 in Kota Timur District, Gorontalo City. This study uses survey evaluation methods. Data writing techniques use questionnaires, documentation, and tests. Data analysis using descriptive analysis. The population is students in grade 4, 5 and class 6 and teachers and principals in the Public Elementary School 61 in Kota Timur Subdistrict, Gorontalo City, totaling 3 classes.
\end{abstract}

Keywords-management, superior school, school-based management

\section{INTRODUCTION}

Improving the quality of education that is enjoyed for the needs of nations who want to advance. With confidence that adequate education can support development in all fields. Therefore, it is necessary to have an understanding of the basis and objectives of education in depth. If we understand the basis and purpose of saying that we can advance school nationally. The basis and purpose of education is a fundamental problem in the implementation of education because the basis of education will determine the style and content of education. The purpose of education will also determine the direction in which students will be brought. For this reason, we must be absolutely right about what is and what can be achieved.

The quality of education is a picture or difference of goods or services that determine its ability to satisfy the right needs. The quality of education is actually a whirlpool of educational activities, steps, strategies, and programs that are oriented towards the education quality round. So the Indonesian government has done many strategies to implement education, making it difficult for us to count, and so on. Education, a change in the management paradigm by implementing school-based management, improving and perfecting the curriculum, improving the education system, increasing the education budget, improving the welfare of educators, building educational facilities, setting national standards for educators, using quality assurance systems, tightening accreditation and many more. Even in the context of education, the quality of education includes good input, process, and output of education.

Management of the quality of education towards a good direction, space is inseparable from the consistency of educational institutions. The national education standard (SNP) is the minimum information regarding the education system in various jurisdictions of the Republic of Indonesia unitary state (Article 1 of RI's RI No. 19 of 2015 p. 12). National standards of education as a basis for planning, implementing and supervising education in order to realize quality national education. National standards of education with the application of eight standards.

The scope of the National Education Standards includes standards, process standards, standards of educators and education personnel, facilities and infrastructure standards, management standards, financing standards, and education standards (Article 2 of the Republic of Indonesia Regulation No. 19 of 2015 p. 15). The factors of input, process, output, and results in education cannot be separated from the standard of education implementation. Eight National Education Standards become the benchmark of management, process, output, and educational outcomes. This standard is once again the minimum requirement for every educational institution. However, the implementation and dissemination of these eight National Education Standards are very large, especially management or management that is not yet "mature", and there are many inequalities. Likewise at SDN 61 Kota Timur, Gorontalo. in pre-research activities, researchers "see" there are factors, both input, process, output that are not in accordance with the National Education Standards (SNP).

TABLE I. LINKAGE OF FACTORS OF INPUT, PROCESS, OUTPUT, AND RESULTS WiTH THE IMPLEMENTATION OF 8 NATIONAL EDUCATION STANDARDS

\begin{tabular}{|l|l|l|}
\hline No. & Factor & \multicolumn{1}{c|}{ Linkage of 8 SNP } \\
\hline 1 & Input & $\begin{array}{l}\text { Standard content } \\
\text { Standards for educators and education personnel } \\
\text { Standard facilities and infrastructure }\end{array}$ \\
\hline 2 & process & $\begin{array}{l}\text { Standard process } \\
\text { Management standards } \\
\text { Financing standards }\end{array}$ \\
\hline 3 & Output & $\begin{array}{l}\text { Graduate competency standard } \\
\text { Educational assessment standard }\end{array}$ \\
\hline 4 & Outcome & - \\
\hline
\end{tabular}


Input is everything that must be available (software or hardware) and is needed for a process to take place. Input can be applied to the education curriculum, students, educators, education personnel, facilities, and infrastructure.

The process of education is the change of something that affects the ongoing process, into something else called output. While output is a school performance or achievement resulting from school processes and behavior [1]. Outcomes are (1) long-term effects of the education process such as acceptance in further education, subsequent achievements and training, employment opportunities, income and further prestige (Lauren Kaluge in Andriansyah [2]) success at work, lifetime income, good citizenship or (2) participant's response to the services provided in a program or (3) the impact, benefits, expectations of change from an activity or service of a program.

One aspect that functions and plays a role in preparing quality human resources is education. In other words, education has a strategic role to create quality human resources. Recognizing the importance of the process of improving the quality of human resources (HR), the government and the private sector seek to develop education in a more quality direction, among others through the development and improvement of curriculum and evaluation, improvement of educational facilities, provision of teaching materials, and training for teachers and other education personnel. But in fact, the government's efforts have not been significant enough to improve the quality (quality) of education [3].

Various efforts have been made by the government to improve the quality of national education. One of them is the implementation of School-Based Management (SBM) which in practice is better known as School-based Quality Improvement Management (MPMBS). In general, MPMBS is defined as a management model that gives schools greater autonomy and encourages participatory decision making that directly involves all school residents to improve the quality of schools based on national education policies [4].

On this side, School-Based Management (SBM) is a way to motivate principals to be more responsible for the quality of students. for this reason, the school principal should develop educational programs as a whole to serve all the needs of students in school [5]. Further stated, all school personnel must participate in formulating a more operational program because they are the parties who are most aware of the needs of their students. In Indonesia, the approach to School-Based Management (SBM) in addition to being positioned as an alternative, is also a criticism of the implementation of education that has been centralized.

Management is an integral component and cannot be separated from the overall educational process. Because without management it is impossible for education goals to be realized optimally, effectively and efficiently. It is in this framework that there is a growing awareness of the importance of School-Based Management (SBM), which gives schools and teachers full authority to regulate education and teaching, plan, organize, supervise, account for, regulate, lead human resources and goods for assist the implementation of learning that is appropriate to the school's objectives [6].

This means that schools as an organization need management that is appropriate to local conditions so that it can encourage the professionalism of teachers and principals in realizing educational goals. SBM is a national policy program which is a priority of the government in an effort to improve the quality of education at the elementary school/madrasah ibtidaiyah level. It is a management model that gives schools greater autonomy to manage existing resources and funding sources. The allocation is in accordance with the priorities of local needs and encourages schools to be able to make decisions related to the implementation of education together from all school residents and the community. Community involvement in School-Based Management (SBM) is intended so that community participation and support can help and control the management of education.

School-Based Management (SBM) is a process of activities carried out jointly between the school and the community in the field of education. Existing human resources are empowered and managed to achieve educational goals. Through School-Based Management (SBM) it is expected that schools can improve their ability to plan, manage, and organize education in schools so that they can improve the quality of education. To achieve the goal of School-Based Management (SBM) maximally, the roles of various parties, both education officials, school supervisors, school heads, teachers and students in schools and the community and parents of students are needed. SBM provides great freedom and power to schools, which of course is accompanied by a set of responsibilities [6], [7]. Providing autonomy to schools is a responsibility for managing existing resources and developing quality improvement strategies through School-Based Management (SBM) that is adapted to local conditions.

In addition to improving the quality of education, SchoolBased Management (SBM) can also increase independence, flexibility, participation, openness, cooperation, accountability, and school initiatives in managing education. On the other hand, School-Based Management (SBM) can increase the awareness of school citizens and the community in the implementation of education through joint decision making. Another benefit of School-Based Management $(\mathrm{SBM})$ is to increase school responsibilities to parents, communities and the government about the quality of their schools and to increase healthy competition between schools about the quality of education to be achieved. Characteristic School-Based Management (SBM) needs to be understood and mastered by the principal as the leader of the institution and will implement it with the human resources in the school. These characteristics include all components of education which include input, process, and output [8], [9].

Raharjo [10] states that Input Education has the following characteristics: (1) having a clear policy, goals and program objectives, (2) resources available and clear, (3) highly competent and dedicated staff, (4) have high achievement expectations, (5) focus on customers, (6) management. Whereas an effective school according to Raharjo [10] has the quality of the educational process as follows: (1) teaching and learning process that has high effectiveness; (2) strong school leadership; (3) a safe, orderly and comfortable school environment; (4) management of effective education personnel; (5) schools have a quality culture; (6) schools have togetherness; (7) schools have authority; (8) participation of school and community residents; (9) management transparency; (10) schools have the will to 
change; (11) schools conduct evaluation and improvement; (12) schools are responsive and anticipatory to needs; (13) good communication; (14) schools have accountability. The expected output or results are school achievements produced through school learning and management processes. Output can be in the form of academic and non-academic achievements. Academic achievements, for example, the results of the school examination, the youth scientific work competition. And the non-academic output, in the form of high curiosity, self-esteem, honesty, good cooperation, tolerance, discipline, sports achievements, art from students and so on.

The assertion of the Implementation of School-Based Management is outlined in the National Education System Law Number 20 of 2003 article 51 paragraph 1 that the management of early childhood education units, primary and secondary education is carried out based on minimum service standards with the principles of School-Based Management. In addition, School-Based Management (MBS) implementation in all formal education units is increasingly clear and firm with the issuance of government policies through Law No. 32 of 2004 concerning Regional Government and Government Regulation No. 25 of 2000 concerning the Distribution of Central Government Authority and Regional Autonomy. Thus there is a shift in authority and freedom in the implementation of all areas of life, including in the field of education. As a form of education management, in the implementation of SchoolBased Management (SBM) it still needs to be strengthened and refined continuously based on weaknesses and shortcomings that exist so that SBM can be implemented properly. To find out these weaknesses and shortcomings, an overall evaluation of the implementation of School-Based Management (SBM) of each component is needed. Wirawan [11] reveals that all programs need to be evaluated to determine whether the service or intervention has reached the stated goals. Similarly, School-Based Management (SBM) which has been implemented in schools needs to be evaluated in order to find out the level of progress of the school in relation to the targets that have been set.

Evaluation is an activity to collect information about the workings of something, which then is used to determine the right alternative in making a decision [12]. Meanwhile, according to Tyler (in Tayibnapis [13]), evaluation is a process that determines the extent to which educational goals can be achieved. Affirmed by Patton [14], that evaluation is a collection, analysis, and systematic interpretation of information about activities and results of real programs according to plan for interested people to make decisions about what specific aspects the program is running and improve the program. Based on the above opinion it can be concluded that evaluation is an activity to determine the extent to which the objectives of a program can be achieved. Evaluation is an integral part of the implementation of School-Based Management (SBM). Evaluation is a stage in School-Based Management (SBM) which is an important activity to find out the progress or results achieved by the school in carrying out its functions in accordance with the plans that have been prepared by each school. For this reason, it is deemed necessary for the writer to examine further about School-Based Management (SBM), especially the evaluation of School-Based Management (SBM) in SD Negeri 61 Kecamatan Timur Timur, Gorontalo City.
The evaluation model used in this study is the CIPP evaluation model developed by Daniel Stufflebeam in 1966. According to Daniel Stufflebeam (in Wirawan [11]), the CIPP model consists of four types of evaluations, namely: Context Evaluation, Input Evaluation, Process Evaluation, and Product Evaluation.

Context Evaluation, which is an evaluation to identify and assess the underlying needs of a program. The main orientation of context evaluation is identifying the background of the need to make changes or the emergence of programs from several subjects involved in decision making. Whether the program objectives and priorities have been designed based on needs analysis.

Input Evaluation, which is an evaluation carried out to identify and assess all available elements because it is needed for the ongoing process. This element must exist before the program starts. In evaluating inputs basically to question whether the educational inputs are ready and sufficient to be used both in terms of quality and quantity. The input components in SBM include human resources (teachers, principals, administration, and students), curriculum, supporting facilities and equipment, and school funds and budgets.

Process Evaluation, namely: an evaluation that aims to access the implementation of the program according to plan. In SBM the elements that are evaluated are the decisionmaking process, the program management process, the teaching-learning process, the school evaluation process. Process evaluation is to question whether the management process of inputs is as expected or has been proven to be good.

Product Evaluation, which is an evaluation conducted in order to see the achievement or success of a program in achieving a predetermined goal.

\section{METHOD}

This study uses survey evaluation methods. Data writing techniques use questionnaires, documentation, and tests. Data analysis using descriptive analysis. The population is students in grade 4, 5 and class 6 and teachers and principals in the Public Elementary School 61 in Kota Timur Subdistrict, Gorontalo City, totaling 3 classes.

\section{RESULT AND DISCUSSION}

Education is a conscious and planned effort to realize a learning atmosphere and learning process so that students actively develop their potential to have religious spiritual strength, self-control, personality, intelligence, noble character, and the skills needed by themselves, society, nation, and state [15]. Education has a strategic role as a means of developing human resources. Education as a scientific activity has measurable goals to be achieved. The aim of education will not be achieved through a simple education process. Education that is able to facilitate change is education that is equitable, quality and relevant to the needs of the community [16].

The government has made various efforts in order to provide hope for the continuity and control of the quality of Indonesian education. But because the management is too rigid and centralistic, various programs implemented by the government do not have a positive impact, even the rate of 
participation in national education and the quality of Indonesian education are declining. The decline in the quality of education is thought to be closely related to management problems so that a thought emerges towards the management of education which gives schools the freedom to regulate and implement various policies widely, the thought of increasing the role of schools in school management is called School-Based Management (SBM) [17].

Schools that implement School-Based Management (SBM) will have the advantage of (1) being more initiative and creative in improving school quality; (2) schools have the flexibility and flexibility in managing their resources, (3) schools are more aware of strengths, weaknesses, opportunities and threats to the survival of the school so that it can anticipate, (4) schools are more aware of their needs so they can adjust to what conditions must be available and can more effectively meet their needs through independent decision making, (5) schools can use school resources more effective because there are controls from various parties and or citizens of the school, (6) schools are more responsible about the quality of education to school stakeholders directly so that schools will be more trying to achieve educational quality through school programs, (7) schools can be faster in respond to the aspirations of school citizens and the environment very dynamic and fast-changing [18].

Schools that implement School-Based Management (SBM) need to understand various characters about the implementation of School-Based Management (SBM) so that improving the quality of education through School-Based Management (SBM) can be achieved. Describing the characteristics of School-Based Management (SBM) through a systematic approach to seeing schools needs to be a system consisting of input, process, and output/school products. School input characteristics in implementing School-Based Management (SBM) are: (1) schools have clear policies, goals and quality objectives, (2) availability of resources that are ready to carry out tasks effectively and (3) have high achievement expectations.

The process character in implementing School-Based Management (SBM) are (1) effective learning, (2) strong school leadership, (3) a safe and orderly school environment, (4) effective management of education personnel, (5) the existence of a culture quality of school citizens, (6) high school citizen participation, (7) management transparency and accountability, and (8) a thorough and sustainable evaluation. The character of school output or product in the implementation of School-Based Management (SBM) is the high academic and non-academic achievement of students [8].

The implementation of School-Based Management (SBM) as an effort to improve the quality of education faces various obstacles and even failures, namely: (1), not all parties are willing to be directly involved in school programs for various reasons; increasing staff development needs that have an impact on increasing education costs, (4) there is confusion due to new tasks and responsibilities, the teacher's tasks are not merely teaching but also must create a conducive learning atmosphere and achieve quality education, (5) accountability and transparency are difficult to realize because transparency is still interpreted as the presentation of transaction evidence not on the accountability of decision making in setting the budget, (6) the principal is too dominant in decision making, has not empowered other school residents in the implementation of school programs, (7) the principal is engaged in administration and no pay attention to the quality of teacher learning, lack of academic supervision of teachers, and (8) parents' participation is often interpreted as fundraising, parents of students too trust in school and have not been involved in efforts to improve the quality of learning directly [4].

The effectiveness of School-Based Management (SBM) must be known from the beginning its impact on the achievement of educational goals, especially in the realization of school programs so that weaknesses can be identified and strengths to be maintained. The criteria for the effectiveness of the implementation of School-Based Management (SBM) need to see the school as a system consisting of input-process-output [17]. To measure the quality of the ongoing program an evaluation process is carried out. The evaluation process that sees a process based on system theory is Stufflebeam and Guba's evaluation model, namely context, input, process and product (CIPP). Through evaluation, it will be known what works, what does not work or fails, what must be changed and what can be maintained [19].

School-Based Management (SBM) is a school management approach that is seen as new to some public schools so there is not much information regarding the ideal implementation of School-Based Management (SBM) in schools. One of the primary schools in Gorontalo that implement School-Based Management (SBM) is SDN 61 Kota Gorontalo. Public Elementary Schools 61 classified as "favorite" schools in Gorontalo City have implemented the concept of school-based management since 2010. Many parents who want to send their children to school at SDN 61 Kota Gorontalo, according to new student admission data 2009 , recorded 160 registrants for 84 seats new student. The achievements of SDN 61 Gorontalo City have been known among the elderly in Gorontalo City, in 2009 it was ranked 1 st in the national final exam in the city of Gorontalo. Researchers are interested in knowing how to implement School-Based Management (SBM) at SDN 61 Gorontalo City with the aim of being a model for implementing SBM so that it can produce high performance. Through the implementation of School-Based Management (SBM), schools are led by school principals, together with all components of the school working to improve the quality of schools by optimizing the role of each component. In practice, schools experience several obstacles related to improving the quality of education through School-Based Management (SBM).

Lexically, School-Based Management (SBM) comes from three words, namely management, based, and school. Management is the process of using resources effectively to achieve goals. Based on having a base word which means basic or principle. Schools are institutions for learning and teaching and places to receive and give lessons. Based on the lexical meaning, School-Based Management (SBM) can be interpreted as the use of resources based on the school itself in the teaching or learning process. In the management context according to School-Based Management (SBM), it is different from previous education management which is all regulated by the central government. In contrast, the education management model of School-Based Management (SBM) is centered on the resources that exist in the school 
itself. Thus, there will be a change in the school management paradigm, which is initially regulated by the bureaucracy outside the school towards management based on the internal potential of the school itself.

School-Based Management (SBM) provides broad power to the school level directly. With the power at the local level of school, management decisions lie with local stakeholders, thus they are empowered to do everything related to school performance. With School-Based Management (SBM) this collective decision-making process can increase the effectiveness of pursuit and increase teacher satisfaction. Although School-Based Management (SBM) gives full power to the school individually, in the school decisionmaking process, it should not be in one hand. When SchoolBased Management (SBM) has not been established, the school decision-making process is often carried out by the school itself internally, led directly by the principal. However, within the framework of School-Based Management (SBM) the decision making process includes participation from various parties, both internal, external, and bureaucratic ranks as supporters. In decision making must be done collectively among school stakeholders.

The evaluation of the CIPP model follows Kaufman \& Thomas [19] as follows:

\section{A. Context Evaluation to Serve Planning Decision}

Context evaluation is the most basic type of evaluation. The aim is to provide logical reasons for targeting. Diagnose problems provide a basis for developing targets whose achievement will lead to improvements in program improvement. Context evaluation methods begin with the conceptual analysis to identify domain boundaries. Then an empirical study was conducted to identify unmet needs and unused opportunities. Finally, context analysis includes both empirical analysis and conceptual analysis.

Context evaluation helps decision planning aims to find out the strengths and weaknesses of the program that are related to the relevance of the educational environment, determine the needs to be achieved, determine the feasibility of the program, describe the desires and factual conditions of the environment, identify gaps in needs encountered.

\section{B. Input Evaluation to Structuring Decision}

Input evaluation is shown to provide information in determining how to use middle-aged sources to achieve program goals or include determining available sources, what alternatives are taken, what plans and strategies to achieve needs, and how work procedures are to achieve them. The pressure of input evaluation is the collection of information used by program decision makers. The decision covers the problems of how to develop instructional programs to make use of resources in achieving the program objectives that have been determined.

\section{Process Evaluation to Serve Implementation Decision}

Process evaluation to help implement decisions, to what extent has the plan been implemented? What must be revised? Is an assessment activity during the implementation of the learning. Process evaluation has in common with formative evaluation. Both are used when the program is being implemented, according to or not with the plan.
Process evaluation is needed to provide periodic feedback to the people responsible for implementing the procedure.

\section{Product Evaluation to Serve Recycling Decision}

Product evacuation aims to measure and interpret achievements not only at the end of program implementation but also during the program. Product evaluation can also be related to the results of program implementation, to assist in subsequent decisions and occur as long as they exist or after the program is completed by emphasizing the collection of information needed to assist decisions regarding the training program. Used as an assessment-assessment to how far the implementation has reached the goal based on the criteria that have been set, and to determine the extent to which the results obtained provide competence to students.

By listening to the four stages in the CIPP model, it is necessary to emphasize the steps used so that the implementation of this model can determine the indicators of the success of a program. Therefore, it needs to pay attention to the steps to use CIPP. According to Kaufman \& Thomas [19] basically, the evaluation of the CIPP model contains three main steps, namely: delineating, obtaining, providing information. The evaluation of the CIPP model basically serves to assist the person in charge of the program in making decisions, namely continuing, modifying, or stopping the program.

However, in decision making that is interpreted as conceptualizing a number of decision processes which include awareness, design, choice, and action, it is necessary to consider the roles played by evaluators. Among them is monitoring a program to identify needs and opportunities to identify concepts, alternative problems to be resolved in adjusting needs or the use of opportunities to assess alternative problem statements from the existing value position and assess whether the problem requires changes and which information can be provided to guide change activities.

To improve the quality of teachers can be by implementing aspects of school-based management. Priyono [20] states "School-Based Management (SBM) is a form of management that gives schools greater autonomy in taking participatory decisions that involve all school residents directly to improve school quality." Then Umaedi [21] stated that "The aspects of school-based management are: planning and evaluating the management of curriculum management learning management of the means of financial management of student services and school relations. Providing broad education autonomy to schools is a concern for the government of Kerala that appears in the community and efforts to improve the quality of education in general.

The granting of autonomy requires a more conducive management approach in schools so that it can accommodate all desires while empowering various components of society effectively to support the progress and systems in schools. So school-based management appears as an alternative to the new paradigm of education management offered. Schoolbased management is a concept that offers autonomy to schools in order to improve quality and equity.

\section{CONCLUSION}

Based on the results of the study conducted a discussion that aims to examine and provide a reflection of the 
exploration of the implementation of SBM in 61 Gorontalo City. The discussion of the results of the study refers to the evaluation of the effectiveness of a system from the aspect of context, input, process, and product of SDN 61 Kota Gorontalo. The effectiveness of the implementation of SBM at SDN 61 Gorontalo City can be seen in the table as follows.

TABLE II. RECAPITULATION OF SBM EFFECTIVENESS IN SDN 61 KOTA GORONTALO

\begin{tabular}{|l|l|c|c|c|c|l|}
\hline No & \multicolumn{1}{|c|}{$\begin{array}{c}\text { MBS } \\
\text { aspects }\end{array}$} & $\begin{array}{c}\text { Achieve- } \\
\text { ment of } \\
\text { Indicator }\end{array}$ & $\begin{array}{c}\text { Standard } \\
\text { Indicator }\end{array}$ & $\begin{array}{c}\text { Achieve- } \\
\text { ment } \\
\text { Standard }\end{array}$ & Percentage & Predicate \\
\hline 1 & Context & 10 & 11 & 10 & $90 \%$ & $\begin{array}{l}\text { Very } \\
\text { effective }\end{array}$ \\
\hline 2 & 15 & 24 & 15 & $62 \%$ & $\begin{array}{l}\text { Effective } \\
\text { enough }\end{array}$ \\
\hline 3 & Input & 16 & 23 & 16 & $70 \%$ & Effective \\
\hline 4 & Process & 8 & 10 & 8 & $80 \%$ & Effective \\
\hline 5 & $\begin{array}{l}\text { All aspects } \\
\text { (context, } \\
\text { input, } \\
\text { process \& } \\
\text { product) }\end{array}$ & 49 & 68 & 59 & $75 \%$ & Effective \\
\hline
\end{tabular}

\section{REFERENCES}

[1] S. Sagala. 2007. Manajemen Strategik dalam Peningkatan Mutu Pendidikan. Bandung: Alfabetta.

[2] E. H. Andriansyah. Pengaruh Standar Nasional Pendidikan Terhadap Kesempatan Kerja Lulusan Akuntansi Melalui Keluaran Satuan Pendidikan SMK Di Kota Surabaya. J. Ekon. Pendidik. Dan Kewirausahaan, vol. 1, no. 1, pp. 26-38, 2017.

[3] A. Zahroh. 2014. Total Quality Management: Teori \& Praktik Manajemen Untuk Mendongkrak Mutu Pendidikan. Yogyakarta: ArRuzz Media.

[4] Nurkolis. 2003. Manajemen berbasis sekolah: teori, model, dan aplikasi. Gramedia Widiasarana Indonesia.
[5] A. M. Fadjar. 2002. Kata Pengantar dalam Ibtisam Abu Duhou. Sch.Based Manag.

[6] E. Mulyasa. 2012. Manajemen dan kepemimpinan kepala sekolah. Jakarta: Bumi Aksara.

[7] A. Hidayat and I. Machali. 2012. Pengelolaan Pendidikan: Konsep, Prinsip dan Aplikasi dalam Mengelola Sekolah dan Madrasah. Yogyakarta: Kaukaba.

[8] K. Menteri. 2004. Keputusan Menteri Pendidikan Nasional Republik Indonesia No. 129a," U2004 Tentang Standar Pelayanan Minimal Bid. Pendidik..

[9] D. Rohiat and M. Pd. 2010. Manajemen sekolah. Bandung: PT Refika Aditama.

[10] B. Raharjo. 2003. Manajemen Berbasis Sekolah. Jakarta: Depdiknas.

[11] E. T. Wirawan and S. Model. 2011. Aplikasi dan Profesi. Persada.

[12] S. Arikunto and C. S. A. Jabar. 2008. Evaluasi Program Pendidikan Pedoman Teoritis Praktis Bagi Mahasiswa dan Praktisi Pendidikan. Jakarta: PT Bumi Aksara.

[13] F. Y. Tayibnapis. 2008. Evaluasi program dan instrumen evaluasi untuk program pendidikan dan penelitian. Jakarta: Rineka Cipta.

[14] M. Q. Patton, B. P. Priyadi, and Kamdani. 2006. Metode evaluasi kualitatif. Pustaka Pelajar.

[15] R. S. Grafika. 2007. UU SISDIKNAS 2003 (UU RI No. 20 Th. 2003). Jakarta: Sinar Grafika.

[16] F. Jalal and D. Supriadi. 2001. Reformasi pendidikan dalam konteks otonomi daerah. Yogyakarta: Adic. Karya Nusa.

[17] E. Mulyasa. 2007. Manajemen Berbasis Madrasah: Konsep, Strategi, dan Implementasi. Bandung: PT Remaja Rosdakarya.

[18] A. Dharma. 2003. Manajemen Berbasis Sekolah: Belajar dari Pengalaman Orang Lain. (Online at http://artikel. us/adharma2. html), accessed at 2 September 2018.

[19] Kaufman, Roger \& Thomas, Susan. 1980. Evaluation withaut fear. New York: New Viewpoints, a division of Franklin Watts.

[20] Priyono. 2000. Manajemen Sumber Daya Manusia. Bandung: Zifatama.

[21] H. Umaedi, "Siswantari. 2008. Manajemen Berbasis Sekolah. Jakarta: Univ. Terbuka. 